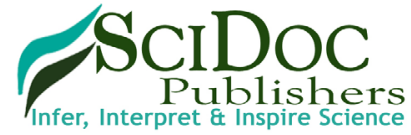

\section{International Journal of Food Science, Nutrition and Dietetics (IJFS)}

ISSN:2326-3350

\title{
Efficacy of Dead Probiotic Cells
}

Editorial

S. Sarkar

Quality Assurance, Metro Dairy Limited, Barrackpore-Barasat Link Road, Subhasnagar, P.O. Neelgunj Bazar, Kolkata, West Bengal, India.

Worldwide consumer's awareness and inclination towards healthful food products capable of conferring health benefits besides providing basic nutrition have led to coin the term functional foods. Foods that contain some health-promoting component(s) beyond traditional nutrients are termed as functional foods. Demonstrated therapeutic evidence has projected probiotics as one of the fastest growing categories of functional food but the market survey of fermented and probiotic containing foods indicated presence of significantly lower levels of viable cells in contrast to those expressed on the product label $[2,4,9]$. In 2013, the global probiotic market was estimated as a value of USD 32.06 billion and is expected to reach USD 52.34 billion by 2020 [3].

FAO/WHO (2001) defines "probiotics as live microorganisms which when administered in adequate amounts confer a health benefit on the host". As per the definition viability of probiotic organisms is prerequisite for exhibiting health benefits and the recommended dosage of probiotics is $10^{8}-10^{10} \mathrm{cfu} /$ day [10]. Ouwehand and Salminen (1998) [11] concluded that both viable and non-viable probiotics may be useful for short-term treatment or prophylactic treatment of diarrhoea, but viable probiotics are necessary for an enhanced immunological response. Recent research has also revealed that viable probiotics are more efficacious than inactivated probiotic products indicating that non-viable probiotics could also have some health benefits $[1,7]$. Equal effectiveness of viable and heat-killed Lactobacillus rhamnosus GG [6] and greater efficacy of heat-killed Lactobacillus acidophilus LB than viable non-specified strain of L. acidophilus [12] for the treatment diarrhoea were noted. Preclinical evidence suggested non association of some mechanisms of probiotic action on cell viability such as adhesion to host tissues and modulation of innate immune responses [7].

It was further denoted that application of inactivated cells may be a safer approach than using live microbes in premature infant immediately after birth or in immuno-suppressed individuals [8]. Further research is emerging to explore the mechanism of action of probiotics and to evaluate whether the live and dead cells have similar efficacy for all diseases or disorders.

\section{References}

[1]. Adams C.A (2010) The probiotic paradox: live and dead cells are biological response modifiers, Nutr. Res. Rev, 23:37-46.

[2]. Al-Otaibi M.M (2009) Evaluation of some probiotic fermented milk products from Al-Ahsa markets, Saudi Arabia, Am. J. Fd. Technol, 4:1-8.

[3]. Anon (2016) Increasing health awareness expected to result in probiotics market size worth USD 52.34 Billion by 2020, Grand View Research, San Francisco, CA 94105, USA.

[4]. Carr J, Ibrahim S.A (2005) Viability of Bifidobacterium in commercial yogurt products in North Carolina Milchwiss, 60: 414-16.

[5]. Reid G (2001) Regulatory and clinical aspects of dairy probiotics: Background paper for the Joint $\mathrm{FAO} / \mathrm{WHO}$ Expert Consultation on Evaluation of Health and Nutritional Properties of Probiotics in Food Including Powder Milk with Live Lactic Acid Bacteria. FAO/WHO, Rome, Italy.

[6]. Kaila M, Isolauri E, Saxelin M, Arvilommi H, Vesikari T (1995) Viable versus inactivated Lactobacillus strain GG in acute rotavirus diarrhoea, Arch. Dis. Child, 72:51-3.

[7]. Lahtinen S.J (2012) Probiotic viability - does it matter, Microbial Ecol. Hlth. Dis, 23:10-14.

[8]. Li N, Russell W.M, Douglas-Escobar M, Mariela Lopez N, Neu J. (2009) Live and Heat-Killed Lactobacillus rhamnosus GG: Effects on pro-inflamatory and anti-inflammatory cytokines/chemokines in gastrostomy-fed infant rats, Pediat. Res. 66:203-7.

[9]. Lin W.H, Hwang C.F, Chen L.W, Tsen H (2006.) Viable counts, characteristic evaluation for commercial lactic acid bacteria products Fd. Microbiol, 23:74-81.

[10]. McFarland LV, Elmer GW (2006) Properties of Evidence-Based Probiotics for Human Health: Probiotics in Food Safety and Human Health. CRC, New York. 109-137.

[11]. Ouwehand A.C, Salminen S (1998) The health effects of cultured milk products with viable and non-viable bacteria, Int. Dairy J, 8:749-58.

[12]. Xiao S.D, Zhang de Z, Lu H, Jiang S.H, Liu H.Y, et al., (2003) Multicenter, randomized, controlled trial of heat-killed Lactobacillus acidophilus LB in patients with chronic diarrhea, Adv. Ther. 20:253-60.

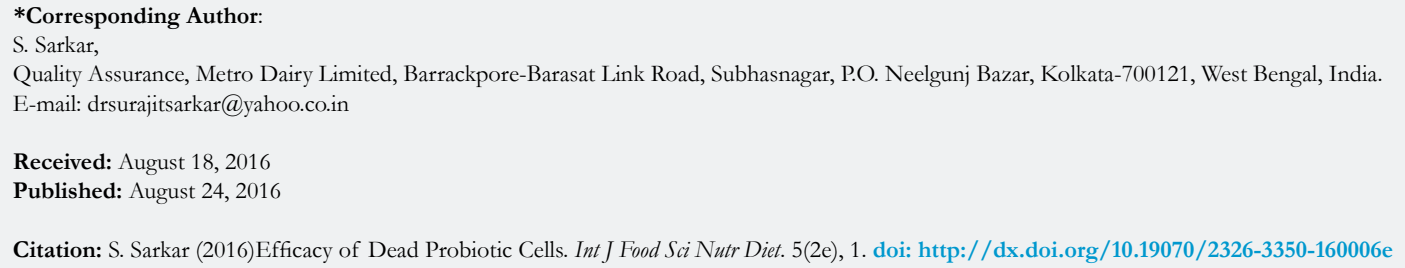

Copyright: S. Sarkar ${ }^{\circ}$ 2016. This is an open-access article distributed under the terms of the Creative Commons Attribution License, which permits unrestricted use, distribution and reproduction in any medium, provided the original author and source are credited. 